\title{
Changes in some Biochemical Parameters of Ivy Gourd (Coccinia Indica Wight and Arn.) Fruits after Infection of Fruit Rot
}

Vaishali Sidram Chatage and Udhav Narba Bhale*

Research laboratory, Department of Botany, Arts, science and Commerce College Naldurg, Tq. Tuljapur. Dist. Osmanabad 413602 (M.S.), India

\begin{abstract}
Biochemical changes were observed from healthy and artificially inoculated carbendazim resistant $\left(\mathrm{Ap}_{13}\right)$ and sensitive $\left(A_{11}\right)$ isolates of Ivy gourd (Coccinia indica) fruit caused by Alternaria pluriseptata (Karst \& Har). There was a significant variation between healthy and infected fruit which showed significant changes with respect to estimation of ash content, total sugar, reducing sugar, non reducing sugar, starch, polyphenol, total ash, Nitrogen, Phosphorus, DNA, RNA, Calcium, Iron, Magnesium, Zinc, Manganese and crude protein. Among them, total sugar (35.4 mg/g) was increased in healthy fruits. But in Polyphenols $(17.401 \mathrm{mg} / 100 \mathrm{gm})$ it was decreased in healthy fruits as compared with infected fruits followed by starch $(15.00 \mathrm{mg} / \mathrm{g})$ and others. Infected fruit of $C$. indica by both resistant and sensitive isolates reduced the contents of all parameters. This was more pronounced due to utilization of nutritious compounds of the fruits by fungal pathogen for their growth and metabolism which causes deterioration of the nutritious compounds of the fruits.
\end{abstract}

Keywords: Alternaria pluriseptata; biochemical changes; Coccinia inidica; Carbendazim

\section{Introduction}

Ivy gourd (Coccina indica Wight and Arn) which belongs to the family Cucurbitaceae, is the most important vegetable and medicinal plant, distributed in Tropical Asia, Africa, Pakistan, India and Sri Lanka $[1,2]$. It is a climber and trailer [3]. The fruit of Coccinia indica is used as vegetable when it is green in colour and eaten fresh when ripened into bright scarlet color. The young leaves and shoot tips of ivy gourd are used in Asia for cooking purpose [4]. Aqueous and ethanolic extracts from the plant have shown hypoglycaemic principles [5,6]. Every part of this plant is valuable in medicine and various preparations which have been mentioned in indigenous system of medicine for skin diseases, bronchial catarrh, and bronchitis and unani systems of medicine [7]. The plant also showed hypoglycemic activities $[8,9,10]$.

There are about 120 genera and 825 species in this family. Members of the Cucurbitaceae are commonly known as gourds or cucurbits and include some important crop species such as Cucumber, Squash, Pumpkin, Luffa and Melons [11]. Most of the plants in this family are annual vines but there are also woody vines, thorny shrubs and trees [12]. Ivy gourd contains vitamin 'A', $\beta$-carotene and is a good source of protein. The phytochemical screening of the $50 \%$ methanolic extract obtained from whole parts of ivy gourd [13] revealed the presence of carbohydrates, glycosides, oil and fats, proteins, amino acids, saponins, tannins, phytosterol, alkaloids, phenolic compounds gum, mucilage and flavonoids. Application of fungicides formed a new tissue, which has protected the expanding tissue and prevented the fruit infection. A single application of the fungicide reduced the postharvest decay up to $25-50 \%$ [14]. The present investigation was made to evaluate the biochemical changes observed in Ivy Gourd due to infected fruit rot caused by $C$. indica.

\section{Materials and Methods}

Total 15 isolates of Alternaria pluriseptata were isolated from infected part of Coccinia indica fruits and maintained on Czapek Dox agar medium (CZA). Alternaria pluriseptata isolates were tested against carbendazim fungicide by food poisoning test [15]. Carbendazim sensitive $\left(A p_{11}\right)$ and resistant $\left(A p_{13}\right)$, isolates were tested for biochemical analysis.
This was studied by inoculating $C$. indica fruits with spore suspension of resistant and sensitive isolates. A deep well $(13 \mathrm{~mm})$ was prepared for spore suspension with the help of cork borer $(8 \mathrm{~mm})$. After inoculation for 8 days, fruits were dried at $40^{\circ} \mathrm{C}$ in hot air oven and powder was obtained after crushing in grinder. The samples were extracted in ethanol and were analyzed for all the biochemical estimations [16]. Altogether 16 parameters were considered for analysis viz, Nitrogen [17], Crude protein [18], sugars and total sugars [19], Nucleic acids (DNA and RNA) [20], Phenols [21] and Ascorbic acids [22].

\section{Results and Discussion}

Fifteen isolates of Alternaria pluriseptata were tested against carbendazim fungicide. The sensitivity (MIC) of carbendazim resistant $\left(A p_{13}\right)$ showed $5000 \mu \mathrm{g} / \mathrm{ml}$ while sensitive $\left(\mathrm{Ap}_{11}\right)$ showed $2900 \mu \mathrm{g} / \mathrm{ml}$. The sensitivity ranged from 2900 to $5000 \mu \mathrm{g} / \mathrm{ml}$ (Table 1). Biochemical analysis determined from fruits of Ivy gourd are shown in (Table 2). It was noted that the content of all parameters in the pathogen varied in sensitive and resistant strains. It was seen that total sugars were reduced in infected fruit of C.indica when compared with healthy ones.

Total sugars in the fruit infected with sensitive and resistant isolates were variable. Among them total sugar $(35.4 \mathrm{mg} / \mathrm{g})$ was increased in healthy fruits, but reduced to sensitive $(25.48 \mathrm{mg} / \mathrm{g})$ and resistant $(28.00$ $\mathrm{mg} / \mathrm{g})$. But in case of Polyphenol it was decreased (17.401 mg/100gm) in healthy however, increased to sensitive $(11.142 \mathrm{mg} / 100 \mathrm{~g})$ and resistant $(12.24 \mathrm{mg} / 100 \mathrm{~g})$ followed by starch. In case of crude protein, Nitrogen, DNA, RNA, and Calcium were decreased due to infection of both isolates. There was slight increase in Polyphenols in fruit inocu-

*Corresponding author: Udhav Narba Bhale, Research laboratory, Department of Botany, Arts, science and Commerce College Naldurg, Tq. Tuljapur Dist Osmanabad 413602 (M.S.), India, E-mail: unbhale2007@redffmail.com

Received April 19, 2012; Accepted June 05, 2012; Published June 07, 2012

Citation: Chatage VS, Bhale UN (2012) Changes in some Biochemical Parameters of Ivy Gourd (Coccinia Indica Wight and Arn.) Fruits after Infection of Fruit Rot. J Plant Pathol Microb 3:122. doi:10.4172/2157-7471.1000122

Copyright: (c) 2012 Chatage VS, et al. This is an open-access article distributed under the terms of the Creative Commons Attribution License, which permits unrestricted use, distribution, and reproduction in any medium, provided the original author and source are credited. 


\begin{tabular}{|l|l|l|}
\hline Isolates & Locations & $\begin{array}{l}\text { Invitro (MIC) } \\
\boldsymbol{\mu g} / \mathbf{m l}\end{array}$ \\
\hline$A p_{1}$ & Naldurg & 3300 \\
\hline$A p_{2}$ & Murum & 3000 \\
\hline$A p_{3}$ & Lohara & 3200 \\
\hline$A p_{4}$ & Osmanabad & 3200 \\
\hline$A p_{5}$ & Omerga & 4100 \\
\hline$A p_{6}$ & Nilanga & 3800 \\
\hline$A p_{7}$ & Paranda & 3000 \\
\hline$A p_{8}$ & Solapur & 3300 \\
\hline$A p_{9}$ & Aurangabad & 3300 \\
\hline$A p_{10}$ & Pune & 3600 \\
\hline$A p_{11}$ & Beed & $2900^{*}$ \\
\hline$A p_{12}$ & Latur & 3500 \\
\hline$A p_{13}$ & Mumbai & $5000^{+}$ \\
\hline$A p_{14}$ & Thane & 3500 \\
\hline$A p_{15}$ & Jalna & 4000 \\
\hline
\end{tabular}

Minimum Inhibitory Concentration (MIC)

* - sensitive +- Resistant

Table 1: Sensitivity (MIC) of carbendazim against Alternaria pluriseptata isolates.

\begin{tabular}{|l|l|c|c|c|}
\hline Sr. No. & Estimation & Healthy & $\begin{array}{c}\text { Sensitive } \\
\left(\mathbf{A p}_{11}\right)\end{array}$ & $\begin{array}{c}\text { Resistant } \\
\left(\mathbf{A p}_{13}\right)\end{array}$ \\
\hline 1 & Nitrogen (\%) & 2.4 & 1.2 & 1.6 \\
\hline 2 & Phosphorus (\%) & 1.6 & 1.00 & 0.601 \\
\hline 3 & Calcium (\%) & 4.9 & 2.7 & 3.8 \\
\hline 4 & Crude protein (\%) & 0.7 & 0.34 & 0.40 \\
\hline 5 & Total Ash (\%) & 1.00 & 0.58 & 0.60 \\
\hline 6 & Total sugar (mg/g) & 35.4 & 25.48 & 28.00 \\
\hline 7 & Reducing sugar (mg/g) & 9.5 & 7.24 & 8.00 \\
\hline 8 & Non reducing sugar(mg/g) & 25.9 & 18.24 & 20.00 \\
\hline 9 & DNA (mg/g) & 3.2 & 1.3 & 1.23 \\
\hline 10 & RNA(mg/g) & 4.9 & 2.10 & 3.25 \\
\hline 11 & Starch (mg/g) & 15.00 & 8.3 & 9.21 \\
\hline 12 & Poly phenols( mg/100gm ) & 17.40 & 11.14 & 12.24 \\
\hline 13 & Magnesium (mg/L) & 0.802 & 0.418 & 0.540 \\
\hline 14 & Manganese( mg/L) & 0.406 & 0.126 & 0.268 \\
\hline 15 & Iron(mg/L) & 1.113 & 0.560 & 1.9 \\
\hline 16 & Zinc(mg/L) & 0.311 & 0.124 & 0.210 \\
\hline
\end{tabular}

Table 2: Estimation of biochemical analysis of healthy and infected fruit of Ivy gourd.

lated with resistant and sensitive isolates in the healthy fruit. In case of Phosphorus and Calcium, it was reduced in infected fruit.

There are reports supporting the characteristic of resistant isolates. There was increase in production of amino acids in the isolate of $\mathrm{Mac}$ rophomina phaseolina resistant to captan and carbendazim [23]. Reduction in DNA content due to infection of resistant Puccinia arachidis on groundnut $[24,25]$, total sugars, total amino acids, crude proteins, and DNA and RNA contents increase in their quantity due to infection by both the isolates of fruit rot of grapes [26]. Biochemical changes in pomegranate fruit infected with carbendazim resistant of Alternaria alternata showed more loss of reducing and non-reducing sugar as compared to healthy one [27]. Total sugars were reduced in infected leaves of spinach when compared with healthy one [28]. The infected bananas showed a decrease in the quantity of total soluble sugar, protein, ash, ascorbic acid and mineral elements when compared with the control of fruit [29]. Total phenols increased in fruits infected by Pestalotiopsis versicolor and Rhizopus arrhizus while reverse was observed in fruits infected by other pathogens [30]. Similarly, the investigation carried out and revealed less content of ascorbic acid, total sugar and capsaicin in fruits heavily infected due to dieback [31]. Biochemical changes were observed from the infected fruit of Cucumis sativus and there was reduction Nitrogen, Protein, ascorbic acid and DNA and RNA due to the infection of fruit rot disease [32].

\section{Conclusion}

Exposure on consumption of these spoiled fruits may be responsible for serious health hazards. The nutritional value of fruits chiefly depends on the quality and quantity of nutritive substances. Various fungi cause rots in fruit of ivy gourd. Post-harvest losses of fruits are very high and diverse post infection; biochemical changes reduce their food and market value considerably. Results of study showed that fungal infection brought about nutritional changes in fruits. This was more pronounced due to utilization by fungal pathogen for their growth and metabolism and causes deterioration of the nutritious of the fruits.

\section{References}

1. Cooke CIET (1903) The Flora of the Presidency of Bombay. The Horticulture Society, USA.

2. Sastri BN (1950) The Wealth of India, a Dictionary of Indian Raw Materials and Industrial Products, Publication and Information Directorate, CSIR New Delhi, 8: 257 and 285-293

3. Nazimuddin S (1984) Flora of West Pakistan, Cucurbitaceae, Botany Department, University of Karachi.

4. Facciola S (1990) Cornucopia: A source book of edible plants, Kampong Publications.

5. Chopra RN, Nayar SL, Chopra IC (1986) Glossary of Indian medicinal plants [with] Supplement, Council of Scientific \& Industrial Research, New Delhi, India.

6. Manandhar NP (2002) Plants and people of Nepal, Timber Press.

7. Behl PN, Arora RB, Srivastava G (1993) Herbs Useful in Dermatological Therapy, CBS, Delhi, India.

8. Gupta SS (1963) Experimental Studies on Pituitary diabetes III Effect of indigenous antidiabetic drugs against the acute hyperglycemic response of anterior pituitary extract in glucose-fed albino rats. Indian J Med Res 51: 716-724.

9. Mukherjee K, Ghosh NC, Datta T (1972) Coccinia indica Linn. as a potential hypoglycaemic agent. Indian J Exp Biol 5: 347-349.

10. Nahar NM, Mosihuzzaman, Khan M, Shahinul H (1998) Determination of free sugars in plant materials having antidiabetic activity. Dhaka Univ J Sci 46: $167-$ 170

11. Andres TC (2004) Website for the plant family Cucurbitaceae and home of 'The Cucurbit Network'.

12. Renner SS, Schaefer H, Kocyan A (2007) Phylogenetics of Cucumis (Cucurbitaceae): Cucumber (C. sativus) belongs in an Asian/Australian and clade far from melon (C.melo). BMC Evol Biol 7: 58.

13. Chandira M, Vankateswarlu BS, Gangwar RK, Sampathkumar KP, Bhowmik D, et al (2010) Studies on anti stress and free radical scavenging activity of whole plant of Coccinia Indica Linn. Int RJ Pharm Sci 01: 0050.

14. Sugar D, Spotts R (1995) Preharvest strategies to reduce decay. In 1995 Washington tree fruit postharvest conference proceedings Washington State horticulturalassociation, Wenatchae, WA.

15. Dekker J, Gielink AJ (1979) Acquired resistance to pimaricin in Cladosporium cucumerinum and Fusarium oxysporum f. sp. narcissi associated with decreased virulence. Eur J Plant Pathol 85: 67-73.

16. Sindhan GS, Prashar RD (1996) Biochemical changes in groundnut leaves due to infection by early and late leaf spot pathogen. Indian J Mycol PI Pathol 26 210-212.

17. Bailey BL (1967) Techiques in protein chemistry IInd Edn. Elsevier Publisling Co., Amsterdam

18. AOAC (1975) Official and tentative methods of analysis. "Association of official agricultural chemist", I,nc. Washington 4 D.C. 
Citation: Chatage VS, Bhale UN (2012) Changes in some Biochemical Parameters of Ivy Gourd (Coccinia Indica Wight and Arn.) Fruits after Infection of Fruit Rot. J Plant Pathol Microb 3:122. doi:10.4172/2157-7471.1000122

19. Ronald S, Sawyer KR (1981) Pearson's chemical analysis of foods. Longman Scientific and Technical, England, 211

20. Plummer DT (1975) An introduction to practical Biochemistry. Tata Mc Graw Hill publisher Ltd., 215-216.

21. Swain T, Hillis WE (1959) The phenolic constituents of Prunus domastics I. The qualitative analysis of phenolic Constituents. J Sci Food Agric 10: 63-68.

22. Gangawane LV, Datar VV (1978) Ascorbic acid content of healthy and Alternaria solani infected tomato germplasm. Indian Phytopathology 31: 237-238.

23. Rana JP, Sengupta PR (1976) Increased production of some Amino Acids; A possible mechanism for mercury and captan tolerance by fungicides adopted isolates of Macrophomina phaseolina, Acta Phytopathol. Acad Sci Hung 11: $65-70$

24. Siddharamaiah AL, Vasuki N, Barama Goudar TD, Lingaraju S, Hegde RK (1980) Biochemical changes in rust infected leaves of groundnut. Indian Phytopathology 32: 640-642.

25. Kareppa BM (1990) Studies on resistance of fungal pathogen to fungicides- III. Ph.D.Thesis, Marathwada University, Aurangabad.
26. Khillare VC, Kadam KS, Gangawane LV (2005) Biochemical changes in host by Aureofungin resistant Alternaria tenuis causing fruit rot of grape. Bioinfolet 2: $77-80$.

27. Bhale UN, Bharade SS, Kamble SS (2009) Biochemical changes in Pomegranate (Punnica granatun L.) fruit infected with Carbendazim resistant of Alternaria alternata (Fr.) Keissler. Biotechnology and Bioinformatics 1: 109-112.

28. Bhale UN, Kamble SS, Gangawane LV (2010) Biochemical changes in spinach infected with carbendazim resistant alternaria spinaciae. Indian Phytopathology 63: $230-231$

29. Sawant SG, Gawai DU (2011) Biochemical Changes in banana fruits due to postharvest fungal pathogens. Current Botany 2: 41-42.

30. Majumdar VL, Pathak VN (1989) Changes in nutritional value of guava fruits infected by major post-harvest pathogens. Plant Foods Hum Nutr 39: 311-315.

31. Khodke SW, Wankhede SG (2000) Biochemical changes in rotted chilli fruits PKV Research Journal 24: 124-125.

32. Hiwale DK (2003) Studies on management of Sclerotium rolfsii, Sacc, fruit rot of Cucumis sativus L. in Maharashtra. Ph.D. Thesis, Dr. Babasaheb Ambedkar Marathawada University, Aurangabad. 